\title{
Space-time evolution of the ecological security of regional urban tourism: the case of Hubei Province, China
}

\author{
Xiuping Yang $\cdot$ Yunting Jia $\cdot$ Qinghe Wang • \\ Chunmei Li $\cdot$ Shixin Zhang
}

Received: 24 November 2020 / Accepted: 22 June 2021 / Published online: 12 August 2021

(C) The Author(s), under exclusive licence to Springer Nature Switzerland AG 2021

\begin{abstract}
While increased tourist demand has brought economic benefits to tourist destinations, it has also put tremendous pressure on tourism-related ecological environments. Therefore, the relationship between regional urban tourism's economic benefits and tourism ecologies must be considered by increasing the ecological security levels of regional urban tourism and promoting sustainable tourism development. This paper defines the ecological security of regional urban tourism, constructs an indicator system of said ecological security based on a pressure-stateresponse social-economic-environment (PSR-SEE) model, uses the entropy method to objectively assign weights to the indicator system, constructs a dynamic multi-scenario simulation model to assess ecological security under continuous, economic priority and various ecological protection scenarios, employs ArcGIS software to analyze the spatial distribution patterns of the ecological security of regional urban tourism, and uses a standard deviation ellipse method to analyze the space-time evolutionary track of the ecological security of regional urban tourism. The index system is applied to 16 cities in Hubei Province to measure the ecological security levels and test the viability of the system. The present research focuses on the space-time evolution of the ecological security of
\end{abstract}

X. Yang $(\bowtie) \cdot$ Y. Jia $\cdot$ Q. Wang $\cdot$ C. Li $\cdot$ S. Zhang

Department of Economy and Management, Lanzhou

University of Technology, Lanzhou 730050, China

e-mail: yangxp789@163.com regional urban tourism, addresses the contradictions between socioeconomic development and the ecological security of regional urban tourism, provides an important reference for tourism destination planning, and can assist in improving the levels of the ecological security of regional urban tourism to promote sustainable tourism development.

Keywords Index system $\cdot$ PSR-SEE model $\cdot$ System dynamics $\cdot$ Multi-scenarios

\section{Introduction}

Maintaining sustainable ecologies in regional tourism destinations requires a focus on ecological security. However, as destination tourism becomes more popular in regional tourist areas, sustaining the ecological security of tourism, which is balancing tourist economy development and tourist ecology protection, has become a significant challenge (Pang et al., 2011). Therefore, developing ecological security plans for regional tourism can protect fragile ecological environments and promote sustainable tourism development.

In 1941, the American ecologist Aldo Leopold proposed the land health concept, which was the application of ecological security measures to the evaluation of land function status, for which he established an evaluation system to measure the land function health status. The early 1980s, which saw a 
plethora of environmental pollution incidents around the world, raised the profile of ecological security in international ecosystem research (Doronkina et al., 2014), with the focus shifting to finding a systematic solution for sound tourism environmental management, which was the precursor to sustainable tourism development (Neven \& Tihomir, 2010). From that time, research on ecological tourism security has focused on the relationship between security and sustainable development.

Research has tended to focus more on tourist security (Hall et al., 2003), the relationship between tourism development and environmental protection, and the ecological, environmental management of tourism (Dey et al., 2018; Neven \& Tihomir, 2010). Therefore, to date, no unified definition for the ecological security of tourism has been offered. To develop a comprehensive, scientific evaluation index system of the ecological security of tourism, indicators need to be developed based on study area characteristics focused on the tourism ecological footprint, the tourism ecological carrying capacity (Wang et al., 2014), and the driving force-pressure-state-impactresponses (Qin \& Cheng, 2019; Weng et al., 2018; Yang \& Weng, 2019). Quantitative studies on the ecological security of tourism have employed various methods, such as an ecology-tourism matrix (ETM) (Jose et al., 2009), a measurement model (Tan et al., 2017), a single-scenario system dynamics model (Espin et al., 2019), a structural equation model (Hedlund, 2011), an analytic network process method (Morteza et al., 2016), and a geospatial assessment method (Brahmasrene \& Lee, 2017). However, as the determination of the evaluation index thresholds and evaluation standards was subjective, the evaluation index system and evaluation standards need further systemization (Zheng et al., 2017), and targeted management tools need to be developed to functionally improve regional urban tourism ecological security levels.

Although there has been some research progress, owing to the lack of a unified definition, evaluation index systems for the ecological security of tourism have been uneven, quantification methods have been inaccurate, there has been a lack of representativeness in the research areas, and the management measures suggested have been routine rather than being specifically focused. The purpose of this paper, therefore, is to analyze and then define the concept of the ecological security of regional urban tourism; construct an indicator system from environmental, economic, and social tourism environment system perspectives; apply the entropy method to determine the appropriate weights for the indicators of the ecological security of regional urban tourism; employ system dynamics to conduct a dynamic multi-scenario simulation; and use ArcGIS to analyze the space-time evolutionary characteristics for the ecological security of regional urban tourism. To conduct this empirical research and propose relevant countermeasures to improve the ecological security levels of regional urban tourism, 16 cities in Hubei Province, China, are taken as case examples to fully realize the "differentiated development" in regional tourist cities.

\section{Defining the ecological security definition of regional urban tourism}

Regional cities could be seen as having continuous but limited spatial scopes and as geographic units made up of one or more environmental factors, economic factors, and social factors. This article defines the ecological security of regional urban tourism as a complex tourism ecosystem in which the environmental, social, and economic tourism resources are maintained in a healthy and non-threatening state through the effective resource management of the ecological environment to allow for further sustainable tourism development.

The ecological security of regional urban tourism is related to the balancing of social progress, economic growth, and environmental care to ensure the derivation of social, economic, and environmental benefits from regional urban tourism development. Therefore, it depends on regional tourism system coordination between sustainable tourism activities and the tourism environment, that is, rational human-land interactions determine the ecological security level of regional urban tourism.

\section{Determining an index system and indicator weight}

Index system

Assessing the ecological security of regional urban tourism is complex as the economic, social, and 
environmental impacts of tourism activities need to be considered from a security perspective. After consulting related studies (Brahmasrene \& Lee, 2017), a pressure-state-response social-economic-environment (PSR-SEE) model was constructed, as shown in Fig. 1. Based on this PSR-SEE model, an indicator system is constructed, which had a target layer, a criterion layer, a feature layer, and an indicator layer, for which 30 indicators were developed. The specific index settings are shown in Table 1.

\section{Indicator weights}

Before determining the weights, to overcome the inconsistent dimensions in the indicators, the indicators need to be normalized. To prevent any index value from being zero during the normalization process, relevant literature was consulted (Yang \& Zhang, 2018) to properly process the positive and negative indicators, the specific processes for which are shown in Eqs. (1) and (2).

Positive indictators : $x_{i j}^{\prime}=\frac{x_{i j}-\min x_{i j}}{\max x_{i j}-\min x_{i j}} \times 0.99+0.01$

Negative indictators : $x_{i j}^{\prime}=\frac{\max x_{i j}-x_{i j}}{\max x_{i j}-\min x_{i j}} \times 0.99+0.01$

In the equations, $i=(1,2, \cdots, m)$ indicates the year, $j=(1,2, \cdots, n)$ indicates the regional urban

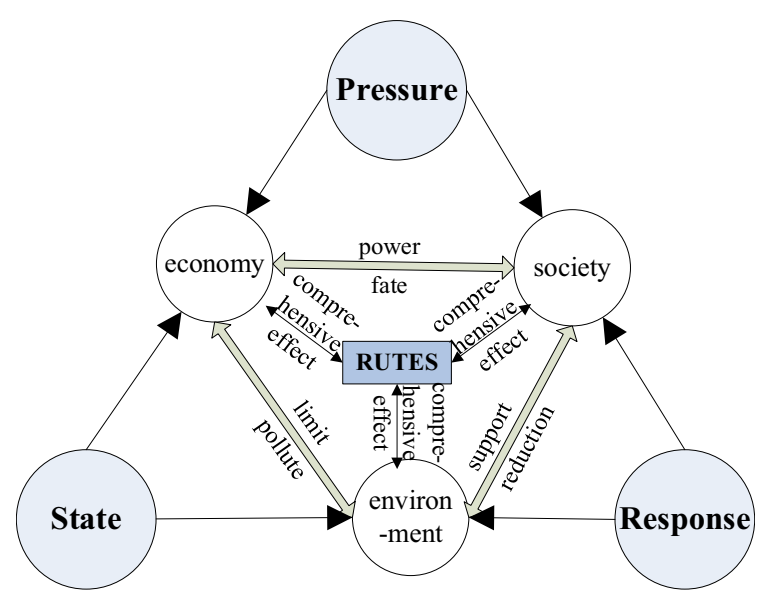

Fig. 1 Pressure-state-response social-economic-environment (PSR-SEE) model tourism ecological security index, $x_{i j}$ indicates the initial value of the index in the first year, $\operatorname{maxx}_{i j}$ and $\min x_{i j}$ indicated the maximum and minimum index values, and $x_{i j}^{\prime}$ is the normalized standard value for $x_{i j}$.

To ensure objectivity, the entropy method is employed to determine the indicator weights. Based on the entropy method principle, after normalizing the ecological security index of regional urban tourism, the proportion of index $j$ in year $i$ to this index is calculated, as shown in Eq. (3).

$M_{i j}=\frac{x_{i j}^{\prime}}{\sum_{i=1}^{m} x_{i j}^{\prime}}$

Subsequently, the information entropy value of the $j$ index is calculated, as shown in Eq. (4).

$N_{j}=-K \sum_{i=1}^{m} M_{i j} \ln M_{i j}$, among them, $K=\frac{1}{\ln m}$

Next, the difference coefficient $A_{j}$ of the index $j$ is calculated again, as shown in Eq. (5).

$A_{j}=1-N_{j}$

Finally, the weight $W_{j}$ of the $j$ index is calculated, as shown in Eq. (6).

$W_{j}=\frac{A_{j}}{\sum_{j=1}^{n} A_{j}}$

\section{Space-time evolution of the ecological security of regional urban tourism}

Time evolution

System dynamics (SD) was first mooted by Professor Forrester of the Massachusetts Institute of Technology in 1956 (Yang \& Zhang, 2018). SD is essentially a computer simulation of the structure and dynamic behavior of complex systems, which is currently implemented using Vensim software. SD has been found to have unique advantages when seeking to deal with multi-element, nonlinear, complex system problems. Therefore, SD can be used to dynamically analyze the overall structure, the mathematical model designs, and the simulations to accurately predict the changing regional urban tourism ecological security 
Table 1 Index system for the ecological security of regional urban tourism

\begin{tabular}{|c|c|c|c|c|c|}
\hline Target layer & Criterion layer & Feature layer & Indicator layer & Unit & References \\
\hline \multirow[t]{19}{*}{$\begin{array}{l}\text { Regional urban } \\
\text { tourism ecological } \\
\text { security C }\end{array}$} & \multirow[t]{10}{*}{$\begin{array}{l}\text { Regional urban } \\
\text { tourism ecological } \\
\text { pressure } \mathrm{C}_{1}\end{array}$} & \multirow[t]{3}{*}{$\begin{array}{l}\text { Economic pressure } \\
\mathrm{C}_{11}\end{array}$} & $\begin{array}{l}\text { Tertiary industry } \\
\text { growth rate } C_{111}\end{array}$ & $\%$ & \multirow[t]{3}{*}{$\begin{array}{l}\text { Li et al. (2015); Xu and } \\
\quad \text { Liu (2018) }\end{array}$} \\
\hline & & & $\begin{array}{l}\text { Fiscal expenditure } \\
\text { as a percentage of } \\
\text { GDP C }_{112}\end{array}$ & $\%$ & \\
\hline & & & $\begin{array}{l}\text { Tourism economic } \\
\text { density } \mathrm{C}_{113}\end{array}$ & $10,000 \mathrm{CNY} / \mathrm{km}^{2}$ & \\
\hline & & \multirow[t]{4}{*}{ Social pressure $C_{12}$} & $\begin{array}{l}\text { Number of tourists } \\
\mathrm{C}_{121}\end{array}$ & 10,000 people & \multirow[t]{4}{*}{$\begin{array}{l}\text { Zhou et al. (2015); } \\
\text { Zheng et al. (2017) }\end{array}$} \\
\hline & & & $\begin{array}{l}\text { Urbanization rate } \\
\mathrm{C}_{122}\end{array}$ & $\%$ & \\
\hline & & & $\begin{array}{l}\text { Total passenger traf- } \\
\text { fic } C_{123}\end{array}$ & 10,000 people & \\
\hline & & & $\begin{array}{l}\text { Tourism space den- } \\
\text { sity } C_{124}\end{array}$ & people $/ \mathrm{km}^{2}$ & \\
\hline & & \multirow[t]{3}{*}{$\begin{array}{l}\text { Environmental pres- } \\
\text { sure } \mathrm{C}_{13}\end{array}$} & $\begin{array}{l}\text { Daily water con- } \\
\text { sumption per capita } \\
\mathrm{C}_{131}\end{array}$ & L/day & \multirow[t]{3}{*}{ Li et al. (2015) } \\
\hline & & & $\begin{array}{l}\text { Domestic waste treat- } \\
\text { ment capacity } C_{132}\end{array}$ & $10,0000 \mathrm{t}$ & \\
\hline & & & $\begin{array}{l}\text { Total sewage dis- } \\
\text { charge } C_{133}\end{array}$ & $10,0000 \mathrm{~m}^{3}$ & \\
\hline & \multirow[t]{9}{*}{$\begin{array}{l}\text { Regional urban } \\
\text { tourism ecological } \\
\text { state } \mathrm{C}_{2}\end{array}$} & \multirow[t]{3}{*}{ Economic state $\mathrm{C}_{21}$} & $\begin{array}{l}\text { Domestic tourism } \\
\text { income } \mathrm{C}_{211}\end{array}$ & billion & \multirow[t]{3}{*}{$\begin{array}{l}\text { Zhou et al. (2015); Wu } \\
\text { et al. (2013) }\end{array}$} \\
\hline & & & $\begin{array}{l}\text { International tourism } \\
\text { income } \mathrm{C}_{212}\end{array}$ & Millions USD & \\
\hline & & & $\begin{array}{l}\text { Total tourism income } \\
\mathrm{C}_{213}\end{array}$ & billion $\mathrm{CNY}$ & \\
\hline & & \multirow[t]{3}{*}{ Social state $\mathrm{C}_{22}$} & $\begin{array}{l}\text { Employees in the } \\
\text { tertiary industry } \\
\mathrm{C}_{221}\end{array}$ & 10 thousand People & \multirow[t]{3}{*}{$\begin{array}{l}\text { Zheng et al. (2017); Xu } \\
\text { et al. (2021) }\end{array}$} \\
\hline & & & $\begin{array}{l}\text { Number of health } \\
\text { institutions } C_{222}\end{array}$ & one & \\
\hline & & & $\begin{array}{l}\text { Tourist reception and } \\
\text { population ratio } \\
\mathrm{C}_{223}\end{array}$ & $\%$ & \\
\hline & & \multirow[t]{3}{*}{$\begin{array}{l}\text { Environmental state } \\
\mathrm{C}_{23}\end{array}$} & $\begin{array}{l}\text { Garden green area } \\
\mathrm{C}_{231}\end{array}$ & Hectare & \multirow[t]{3}{*}{$\begin{array}{l}\text { Li et al. (2015); Zhou } \\
\text { et al. (2015) }\end{array}$} \\
\hline & & & $\begin{array}{l}\text { Green coverage in } \\
\text { built-up areas } C_{232}\end{array}$ & $\%$ & \\
\hline & & & $\begin{array}{l}\text { Park area per capita } \\
\mathrm{C}_{233}\end{array}$ & $\mathrm{~m}^{2} /$ person & \\
\hline
\end{tabular}


Table 1 (continued)

\begin{tabular}{|c|c|c|c|c|c|}
\hline Target layer & Criterion layer & Feature layer & Indicator layer & Unit & References \\
\hline & \multirow[t]{11}{*}{$\begin{array}{l}\text { Regional urban } \\
\text { tourism ecological } \\
\text { response } \mathrm{C}_{3}\end{array}$} & \multirow[t]{5}{*}{$\begin{array}{l}\text { Economic response } \\
\mathrm{C}_{31}\end{array}$} & $\mathrm{GDP}_{311}$ & billion $\mathrm{CNY}$ & \multirow[t]{5}{*}{$\begin{array}{l}\text { Li et al. (2015); Zhou } \\
\text { et al. (2015); Qin and } \\
\text { Cheng (2019) }\end{array}$} \\
\hline & & & $\begin{array}{l}\text { Tourism income per } \\
\text { capita } \mathrm{C}_{312}\end{array}$ & $\mathrm{CNY}$ & \\
\hline & & & $\begin{array}{l}\text { Total tourism income } \\
\text { as a percentage of } \\
\text { GDP } C_{313}\end{array}$ & $\%$ & \\
\hline & & & $\begin{array}{l}\text { Proportion of urban } \\
\text { tertiary industry } \\
\mathrm{C}_{314}\end{array}$ & $\%$ & \\
\hline & & & $\begin{array}{l}\text { Fiscal revenue as a } \\
\text { percentage of GDP } \\
\mathrm{C}_{315}\end{array}$ & $\%$ & \\
\hline & & \multirow[t]{3}{*}{ Social response $\mathrm{C}_{32}$} & $\begin{array}{l}\text { Energy-saving and } \\
\text { environmental pro- } \\
\text { tection expenditure } \\
\text { as a percentage of } \\
\text { GDP C }_{321}\end{array}$ & $\%$ & \multirow[t]{3}{*}{ Qin \& Cheng, 2019} \\
\hline & & & $\begin{array}{l}\text { Education expendi- } \\
\text { ture as a percentage } \\
\text { of GDP } \mathrm{C}_{322}\end{array}$ & $\%$ & \\
\hline & & & $\begin{array}{l}\text { Number of students } \\
\text { in regular colleges } \\
\text { and universities } \\
\mathrm{C}_{323}\end{array}$ & 10,000 people & \\
\hline & & \multirow[t]{3}{*}{$\begin{array}{l}\text { Environmental } \\
\text { response } \mathrm{C}_{33}\end{array}$} & $\begin{array}{l}\text { General industrial } \\
\text { solid waste utiliza- } \\
\text { tion rate } \mathrm{C}_{331}\end{array}$ & $\%$ & \multirow[t]{3}{*}{$\begin{array}{l}\text { Li et al. (2015); Zhou } \\
\text { et al. }(2015)\end{array}$} \\
\hline & & & $\begin{array}{l}\text { Domestic sewage } \\
\text { treatment rate } \mathrm{C}_{332}\end{array}$ & $\%$ & \\
\hline & & & $\begin{array}{l}\text { Harmless treatment } \\
\text { rate of domestic } \\
\text { garbage } C_{333}\end{array}$ & $\%$ & \\
\hline
\end{tabular}

processes. The tourism eco-environment system is a complex system composed of various elements that need to be evaluated and predicted using SD simulations. The SD model construction is divided into clear problems to determine the system boundary, from which a dynamic hypothesis is proposed, equations are developed, the design is tested, and policies proposed, after which the system is evaluated. To construct the variable equations, the following were used: Eqs. (7)-(10)

$$
\begin{aligned}
& f(x)=\sum_{i=1}^{m} a_{i} \times x_{i} \\
& g(y)=\sum_{j=1}^{n} b_{j} \times y_{j}
\end{aligned}
$$

$(s)=\sum_{k=1}^{z} c_{k} \times s_{k}$

RUTES $=w_{1} \times f(x)+w_{2} \times g(y)+w_{3} \times h(s)$

where $a_{i}, b_{j}$, and $c_{k}$ are the weights for the relevant regional urban tourism ecological security subsystem indicators; $x_{i}, y_{j}$, and $s_{k}$ are the numerical values for the relevant indicators; $f(x), g(y)$, and $h(s)$ are the respective values for the pressure, state, and response subsystems; $m, n$, and $k$ are the respective related indicators for the pressure, state, and response subsystems; RUTES is the regional urban tourism ecological security; and $w_{1}, w_{2}$, and $w_{3}$ are the respective weights corresponding to the relevant indicators in the pressure, state, and response subsystems. 
Fig. 2 Causality diagram of the variables for the ecological security of regional urban tourism

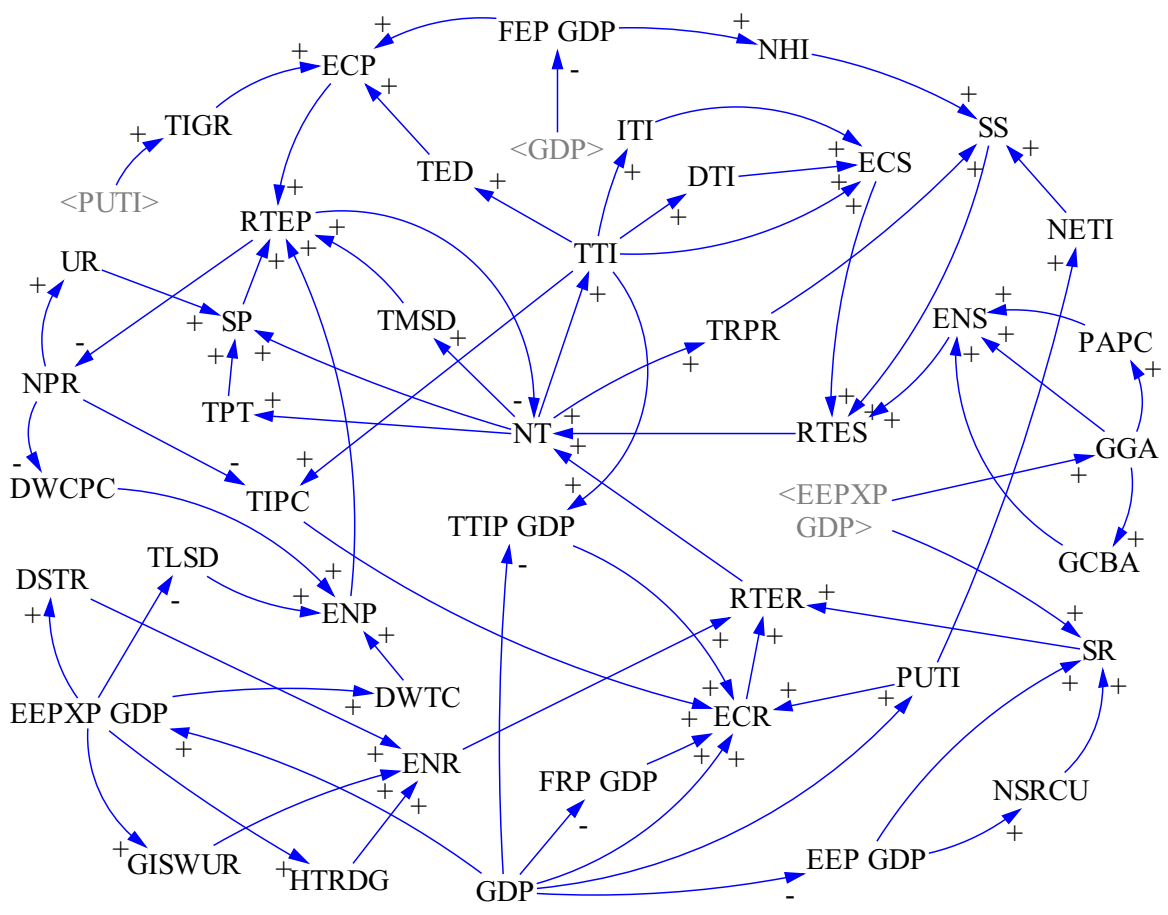

As shown in Fig. 2, a causal relationship between the main indicators of the ecological security of regional urban tourism is constructed from pressure, state, and response subsystem perspectives, from which the SD model is established (Fig. 3). The security scenarios were divided into a "continuous scenario," an "economic priority scenario," and an "ecological protection scenario" to conduct the prediction research on the ecological security of tourism and discuss the tourism ecological pressure, the tourism ecological state, and the tourism ecological responses in specific areas.

The following indices are shown in Figs. 2 and 3: tertiary industry growth rate, fiscal expenditure, fiscal expenditure as a percentage of GDP (FEP GDP), tourism economic density, number of tourists, urbanization rate (UR), total passenger traffic, tourism space density (TMSD), daily water consumption per capita, domestic waste treatment capacity (DWTC), total sewage discharge (TLSD), domestic tourism income, international tourism income, total tourism income, number of employees in the tertiary industry (NETI), number of health institutions, tourist reception and population ratio, garden green area (GGA), green coverage of built-up area, park area per capita (PAPC), GDP/tourism income per capita, total tourism income as a percentage of GDP (TTIP GDP), proportion of urban tertiary industry, fiscal revenue(FR), fiscal revenue as a percentage of GDP (FRP GDP), energy conservation and environmental protection expenditure, energy-saving and environmental protection expenditure as a percentage of GDP (EEPEP GDP), education expenditure, education expenditure as a percentage of GDP (EEPGDP), number of students in regular colleges and universities, general industrial solid waste utilization rate, domestic sewage treatment rate, harmless treatment rate of domestic garbage, number of permanent residents, administrative area, value-added for primary industry, value-added for secondary industry, valueadded for tertiary industry, economic pressure (ECP), social pressure (SP), environmental pressure (ENP), regional urban tourism ecological pressure, economic state (ECS), social state (SS), environmental state (ENS), regional urban tourism ecological state, economic response (ECR), social response, environmental response (ENR), and regional urban tourism ecological response. In addition, $\Delta$ represents an increase of a certain amount, and -GR represents the growth rate of a certain amount. 


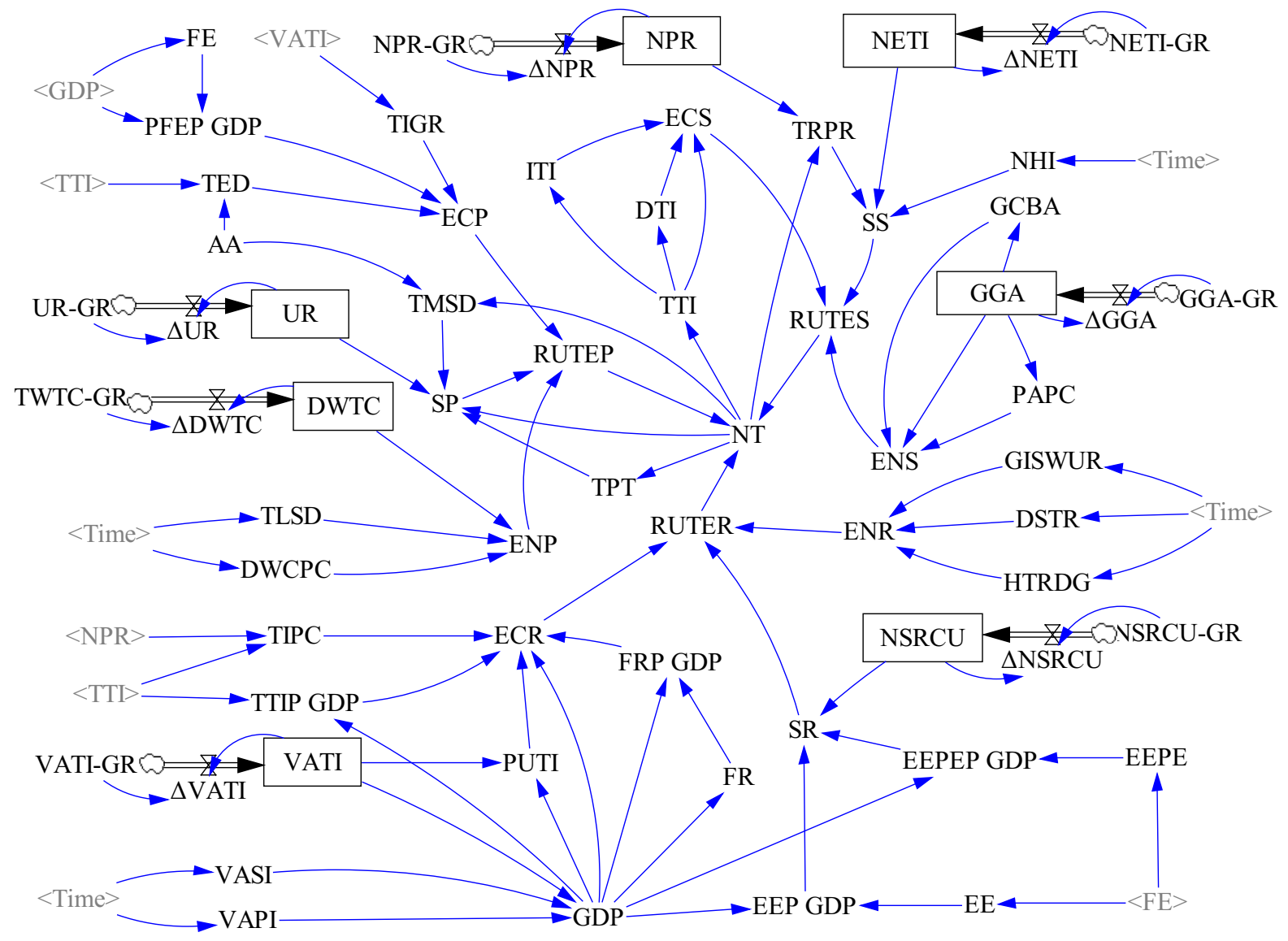

Fig. 3 Stock flow chart for the ecological security of regional urban tourism

Classifying the ecological security of regional urban tourism

There has not yet been a unified standard for the classification of the ecological security of regional urban tourism because of the uneven social-economic development levels in such ecological environments and the inconsistencies in the tourism development policy implementation effects in specific regions. Based on related literature (Bangwayo-Skeete \& Skeete, 2020; Shadova et al., 2015), the ecological security levels of regional urban tourism are divided as in Table 2.
Space evolution for regional urban tourism ecological security

The standard deviational ellipse (SDE), which delineates the geographic distribution of concerned features using a GIS tool, was proposed by Lefever in 1926 (Li et al., 2015); therefore, to describe the spatial agglomeration distribution trends and the regional urban tourism ecological security value expansion directions, the space-time evolutionary trajectory of the ecological security of regional urban tourism is analyzed based on the SDE method using the ellipse's

Table 2 Classification standards for the ecological security of regional urban tourism

\begin{tabular}{llllllll}
\hline Index & {$[0,0.05]$} & $(0.05,0.10]$ & $(0.1,0.20]$ & $(0.20,0.40]$ & $(0.40,0.60]$ & $(0.60,0.80]$ & $(0.80,1.00]$ \\
\hline Level & $\begin{array}{c}\text { Deterioration } \\
\text { level (I) }\end{array}$ & Risk level (II) & $\begin{array}{c}\text { Sensitivity level } \\
\text { (III) }\end{array}$ & $\begin{array}{c}\text { Critical security } \\
\text { level (IV) }\end{array}$ & $\begin{array}{c}\text { General security } \\
\text { level (V) }\end{array}$ & $\begin{array}{c}\text { Compare secu- } \\
\text { rity level (VI) }\end{array}$ & $\begin{array}{c}\text { Very security } \\
\text { level (VII) }\end{array}$ \\
\hline
\end{tabular}


semi-major axis, the semi-minor axis, the direction angle, and other parameters. The specific calculations are shown in Eqs. (11)-(13), with

the average center,

$$
\bar{X}=\frac{\sum_{i=1}^{n} w_{i} x_{i}}{\sum_{i=1}^{n} w_{i}}, \bar{Y}=\frac{\sum_{i=1}^{n} w_{i} y_{i}}{\sum_{i=1}^{n} w_{i}}
$$

the SDE,

$$
\begin{aligned}
& X_{S D E}=\sqrt{\frac{\sum_{i=1}^{n} w_{i}^{2}\left(x_{i}^{\prime} \cos \theta-y_{i}^{\prime} \sin \theta\right)^{2}}{\sum_{i=1}^{n} w_{i}^{2}}} \\
& Y_{S D E}=\sqrt{\frac{\sum_{i=1}^{n} w_{i}^{2}\left(x_{i}^{\prime} \sin \theta-y_{i}^{\prime} \cos \theta\right)^{2}}{\sum_{i=1}^{n} w_{i}^{2}}}
\end{aligned}
$$

and the abscissa direction angle,

$$
\begin{aligned}
& \tan \theta=\frac{M+N}{Q} \\
& M=\sum_{i=1}^{n} w_{i}^{2} x_{i}^{\prime 2}-\sum_{i=1}^{n} w_{i}^{2} y_{i}^{\prime 2} \\
& N=\sqrt{\left(\sum_{i=1}^{n} w_{i}^{2} x_{i}^{\prime 2}-\sum_{i=1}^{n} w_{i}^{2} y_{i}^{\prime 2}\right)^{2}+4\left(\sum_{i=1}^{n} w_{i}^{2} x_{i}^{\prime} y_{i}^{\prime}\right)^{2}} \\
& Q=2 \sum_{i=1}^{n} w_{i}^{2} x_{i}^{\prime 2} y_{i}^{\prime 2}
\end{aligned}
$$

where $\bar{X}$ and $\bar{Y}$ represent the horizontal and vertical coordinates of the region's center of gravity, $x_{i}$ and $y_{i}$ represent the horizontal and vertical coordinates of the first region, $n$ is the number of regions, $x_{i}^{\prime}$ and $y_{i}^{\prime}$ represent the regional coordinates and center of gravity deviation, and $w_{i}$ is the attribute value for the spatial element.

Therefore, the regional urban tourism ecological security level is measured based on the entropy value method, SD, and the SDE method. The ecological security levels of regional urban tourism in different time regions under three different "continuous," "economic priority," and "ecological protection" scenarios are then entered into ArcGIS 10.2 to visualize the changing trends at different times and in different spaces so as to provide practical suggestions for promoting sustainable tourism development in the research area.

\section{Case analysis}

Overview of Hubei Province and data sources

Hubei Province is located at $108^{\circ} 21^{\prime} 42^{\prime \prime}-116^{\circ} 07^{\prime}$ E, $29^{\circ} 01^{\prime}-33^{\circ} 6^{\prime} 47^{\prime \prime} \mathrm{N}$, in south-central China on the middle reaches of the Yangtze River and north of Dongting Lake and has a total area of $185,900 \mathrm{~km}^{2}$, or $1.94 \%$ of China's total area. Hubei Province has a unique strategic location advantage, is an important hub for China in the Yangtze River Economic Belt and the "One Belt and One Road" development strategy, and is an important strategic fulcrum for the huge development potential in central China. Hubei Province has 17 cities: Wuhan, Huangshi, Shiyan, Yichang, Xiangyang, Ezhou, Jingmen, Xiaogan, Jingzhou, Huanggang, Xianning, Suizhou, Enshi Tujia and Miao Autonomous prefecture, Xiantao, Qianjing, Tianmen, and the Shennongjia Forest Area (Fig. 4).

Tourist attraction rating categories refer to a rating system used by the Chinese authorities to determine the quality of an attraction relative to its peers in terms of safety, cleanliness, sanitation, and transportation. There are five categories: A (or 1A, the lowest level), AA (2A), AAA (3A), AAAA (4A), and AAAAA (5A, the highest level). Hubei Province has a long history and rich tourism resources. As of 2018, Hubei Province had 350 star-rated hotels, 1777 travel agencies, and 110 scenic spots above $3 \mathrm{~A}$ (out of 5 as per the Chinese tourist spot rating system). In 2018, Hubei Province had 7,265,869 million tourists, from which the total tourism revenue was 634.433 billion CNY. While this rapid tourism industry development has driven the growth in the local economy, the negative impact on the tourism ecological environment cannot be ignored. Therefore, it is extremely important to assess the ecological security of regional tourism in Hubei Province. Because of the lack of data from the Shennongjia Forest Area, this article focuses on the regional urban tourism ecological security in the 16 other cities. The data used for the evaluation indicators in this article are taken from the Hubei 


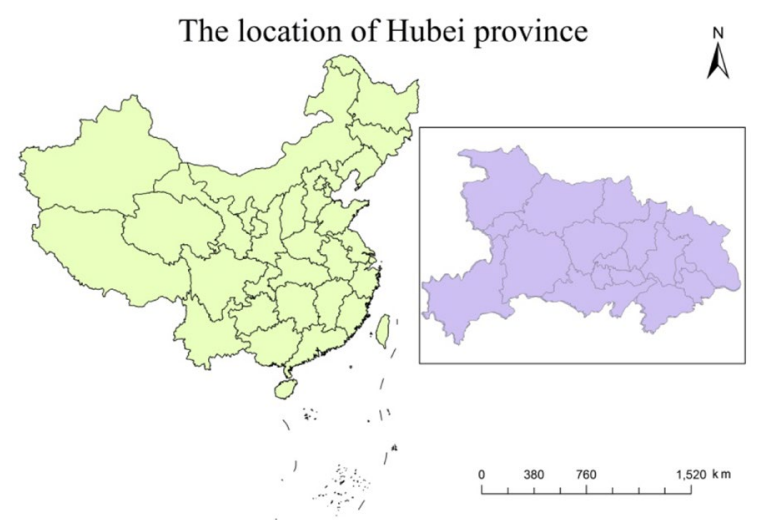

Fig. 4 The location of Hubei Province

Statistical Yearbooks (2010-2019), the China City Construction Statistical Yearbooks, the China Tourism Statistical Yearbooks (2010-2019), various city statistical yearbooks (2010-2019), statistical national economic and social development city bulletins (2010-2019), and the official National Bureau of Statistics website. In instances of missing data, the adjacent data are averaged and an SPSS linear regression is applied.

Ecological security of regional urban tourism in Hubei Province

The current ecological security situations of tourism in the 16 Hubei Province cities and prefectures are determined based on the normalized data from 2009 to 2018 (Eqs. (1) and (2)), with the entropy method used to determine the index system weights (Eqs. (3)-(6)), as shown in Table 3. Eqs. (7)-(10) are applied to measure the ecological security levels of tourism in the 16 Hubei Province cities, the results for which are shown in Table 4.

As can be seen, from 2009 to 2018, the development trends and ecological security levels of regional urban tourism in the 16 cities varied significantly. Except for Shiyan, Xiangyang, Ezhou, and Suizhou, the overall security levels in the other 12 cities are rising, and the development is relatively stable. Therefore, although there is certain volatility during the period, the overall trend is slowly increasing, slowly decreasing, and continuing to develop. However, although the security levels are improving, the overall level is still low. Therefore, joint efforts by relevant stakeholders such as the government, tourism companies, tourist destination residents, and tourists are needed.

Dynamic time simulation of the ecological security of regional urban tourism in Hubei Province

As shown in the SD model in Fig. 3, to build the theoretical SD model for the ecological security of regional urban tourism in relation to the 16 Hubei Province cities and test the theoretical model, the start time is set at 2009 and the end time is set at 2025 (units: year), with the time step being 1 (units: year). The model is revised based on the indicator sensitivities such as UR, DWTC, NETI, and GGA, with the statistical data from 2009 to 2018 being tested within a floating range of $10 \%$ (Dogru et al., 2019) (the UR was taken as an example in Table 3). Using Vensim software, dynamic simulations and ecological security predictions for the 16 cities are conducted, the change trends in and evolutionary characteristics of the ecological security of regional urban tourism are explored over time, as shown in Fig. 5, and the ecological security levels of regional urban tourism are simulated under multi-scenarios, as shown in Table 5.

As shown in Fig. 5, over time, the overall ecological security levels in the 16 Hubei Province cities have an upward trend. Under the continuous, economic priority, and ecological protection scenarios from 2009 to 2015 , the ecological security levels of urban tourism appear to converge. However, after 2015, there are obvious differences in the ecological security levels in the three different scenarios. The ecological security levels of regional urban tourism under the ecological protection scenario have the fastest growth rate and the highest development, and the overall ecological security level of tourism under the economic priority scenario is higher than under the continuous scenario. Although when compared to maintaining the status quo, accelerating economic development could improve the ecological security of regional urban tourism, a one-sided pursuit of rapid economic development and an ignorance of the ecological environmental protection of tourism would not conducive to sustainable tourism development (Banerjee et al., 2018). Only increasing ecological environmental protection can improve the ecological security of regional urban tourism. 


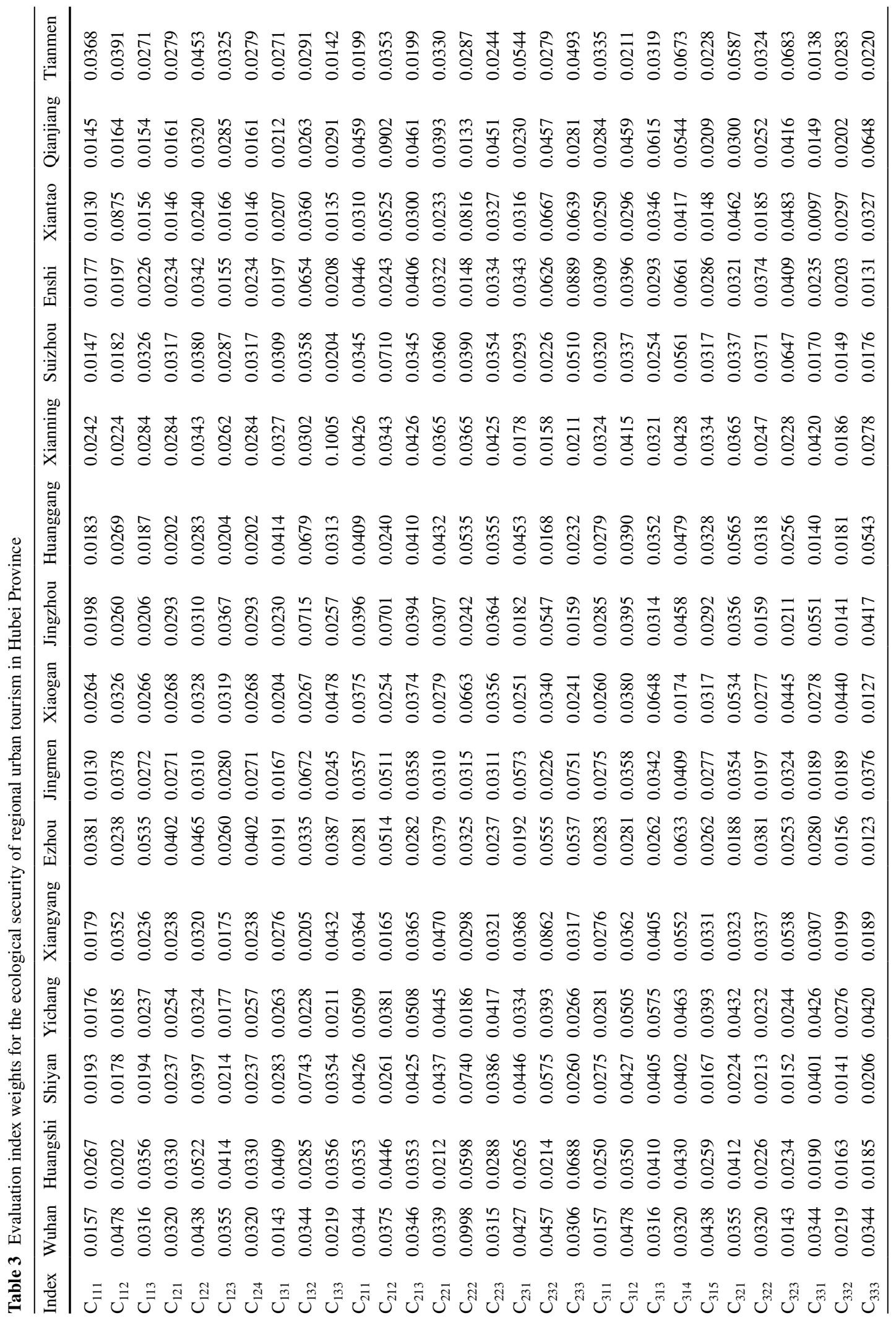


Table 4 Ecological security levels of regional urban tourism in Hubei Province (2009-2018)

\begin{tabular}{lllllllllll}
\hline City & 2009 & 2010 & 2011 & 2012 & 2013 & 2014 & 2015 & 2016 & 2017 & 2018 \\
\hline Wuhan & 0.1416 & 0.1602 & 0.1812 & 0.2017 & 0.2181 & 0.2357 & 0.2660 & 0.2858 & 0.3087 & 0.3447 \\
Huangshi & 0.0562 & 0.0408 & 0.0514 & 0.0516 & 0.0525 & 0.0519 & 0.0594 & 0.0573 & 0.0600 & 0.0613 \\
Shiyan & 0.0948 & 0.0444 & 0.0292 & 0.0200 & 0.0248 & 0.0344 & 0.0438 & 0.0581 & 0.0653 & 0.0746 \\
Yichang & 0.0697 & 0.0730 & 0.0805 & 0.0884 & 0.1009 & 0.1139 & 0.1176 & 0.1303 & 0.1422 & 0.1623 \\
Xiangyang & 0.1017 & 0.0491 & 0.0596 & 0.0529 & 0.0570 & 0.0592 & 0.0678 & 0.0744 & 0.0812 & 0.0828 \\
Ezhou & 0.0917 & 0.0791 & 0.0820 & 0.0636 & 0.0628 & 0.0522 & 0.0560 & 0.0651 & 0.0686 & 0.0674 \\
Jingmen & 0.0540 & 0.0368 & 0.0371 & 0.0373 & 0.0301 & 0.0452 & 0.0484 & 0.0534 & 0.0623 & 0.0615 \\
Xiaogan & 0.0564 & 0.0573 & 0.0611 & 0.0569 & 0.0523 & 0.0519 & 0.0545 & 0.0549 & 0.0498 & 0.0681 \\
Jingzhou & 0.0590 & 0.0670 & 0.0772 & 0.0851 & 0.0689 & 0.0764 & 0.0788 & 0.0952 & 0.1011 & 0.0972 \\
Huanggang & 0.0900 & 0.0877 & 0.0824 & 0.0831 & 0.0856 & 0.0880 & 0.0907 & 0.1000 & 0.1050 & 0.1141 \\
Xianning & 0.0513 & 0.0358 & 0.0361 & 0.0337 & 0.0371 & 0.0365 & 0.0396 & 0.0519 & 0.0505 & 0.0562 \\
Suizhou & 0.0458 & 0.0098 & 0.0116 & 0.0097 & 0.0136 & 0.0173 & 0.0216 & 0.0217 & 0.0279 & 0.0306 \\
Enshi & 0.0850 & 0.0606 & 0.0567 & 0.0588 & 0.0636 & 0.0664 & 0.0804 & 0.0826 & 0.0905 & 0.1262 \\
Xiantao & 0.0594 & 0.0627 & 0.0590 & 0.0592 & 0.0580 & 0.0590 & 0.0687 & 0.0684 & 0.0701 & 0.0764 \\
Qianjiang & 0.0356 & 0.0357 & 0.0310 & 0.0325 & 0.0369 & 0.0464 & 0.0562 & 0.0491 & 0.0483 & 0.0517 \\
Tianmen & 0.0490 & 0.0300 & 0.0311 & 0.0439 & 0.0439 & 0.0419 & 0.0538 & 0.0461 & 0.0507 & 0.0563 \\
\hline
\end{tabular}

Spatial dynamic simulation of the ecological security of regional urban tourism in Hubei Province

The results from the dynamic simulation and prediction of the ecological security levels in the 16 Hubei Province cities are imported into ArcGIS 10.2 for visualization, and the spatial change trends and evolutionary characteristics spatially explored, as shown in Fig. 6.

As can be seen in Fig. 6, in 2009, there were no differences in the 16 Hubei Province cities under the three different scenarios. Over time, the ecological security levels of regional urban tourism in the 16 cities gradually increased, with Wuhan, the capital of Hubei Province, having a larger growth rate and final value under the economic priority and ecological protection scenarios, which also confirmed that vigorously developing the economy and increasing ecological and environmental protections had obvious effects in Wuhan. Besides Wuhan, Yichang have the fastest growing levels under the continuous and economic priority scenarios, with its ecological security level ranging from a risk level to a sensitive level to a compare security level. Under the ecological protection scenario, the ecological security level of regional urban tourism is expected to eventually move to a very secure level, indicating that developments would need to be focused on continuous or economic development scenarios. That is, although the level in Yichang is expected to improve, to ensure sustainable tourism development, greater efforts should be placed on increasing ecological and environmental tourism protection to increase the security level more quickly.

Compared to Wuhan and Yichang, the ecological security level growth rates and final values in the remaining 14 cities are lower. However, they are higher under the "ecological protection scenario" than under the "economic priority" or "continuous" scenarios.

According to Eqs. (12)-(13), the change trends for the SDE and the center of gravity evolution trajectory are drawn using ArcGIS 10.2. To more deeply study the temporal and spatial evolutionary characteristics of the ecological security of regional urban tourism in Hubei Province, data from 2009, 2018, and 2025 are selected under the three scenarios to examine the status quo continuity, economic priority, and ecological protection. Figure 7 and Table 6 show the specific SDE parameters for the ecological security levels in Hubei Province under the different scenarios.

As can be seen from Fig. 7 and Table 6, under the continuous scenario from 2009 to 2018 , the ecological security of regional urban tourism in Hubei Province moved to the southeast, indicating that the overall ecological security in the southeast is increasing. From 2019 to 2025, the ecological security level 


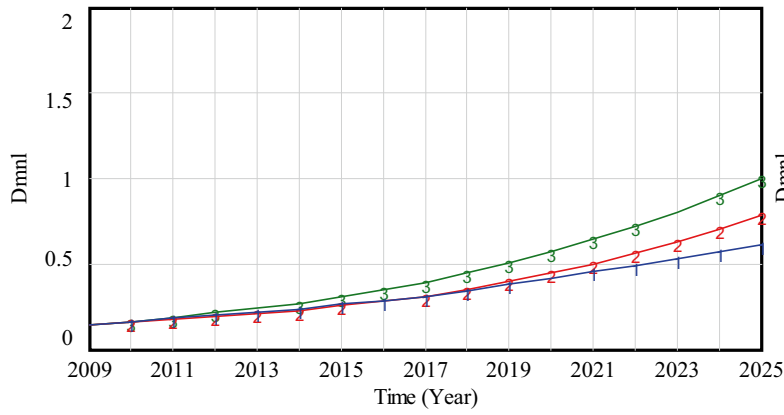

Wuhan RUTES : Q1 Wuhan RUTES : Q2 $\quad \begin{array}{llll}2 & 2 & 2\end{array}$

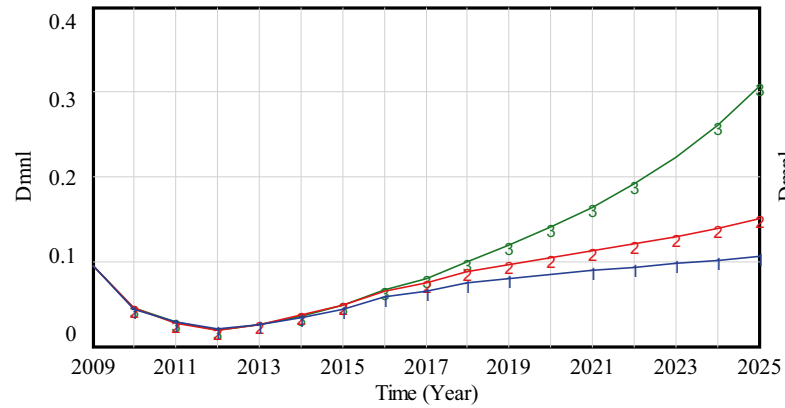

Shiyan RUTES : Q1 Shiyan RUTES : Q2 $\quad \begin{array}{lll}2 & 2 & 2\end{array}$

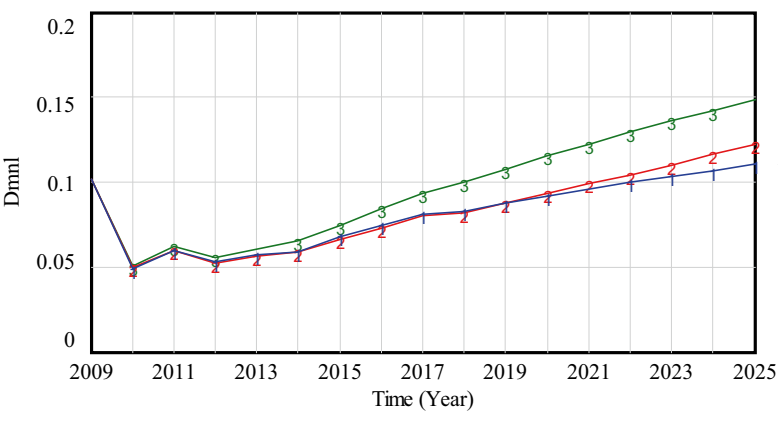

Xiangyang RUTES : Q1 $\longrightarrow$ Xiangyang RUTES : Q3 3 Xiangyang RUTES : Q2

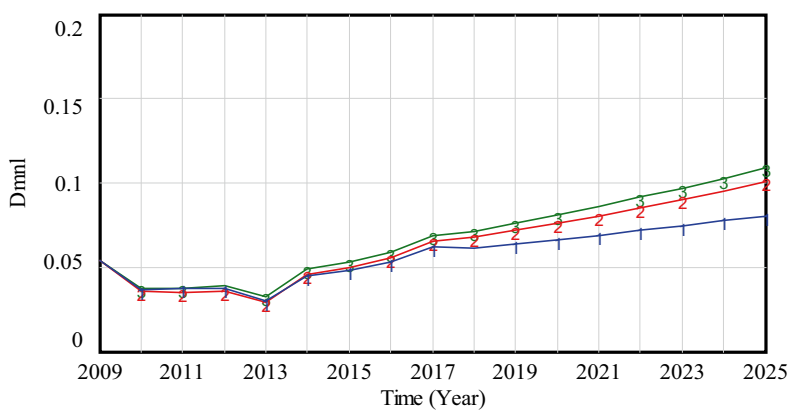

Jingmen RUTES : Q1 Jingmen RUTES : Q2 $\mathrm{Z}_{2} \mathrm{Z}_{2}$

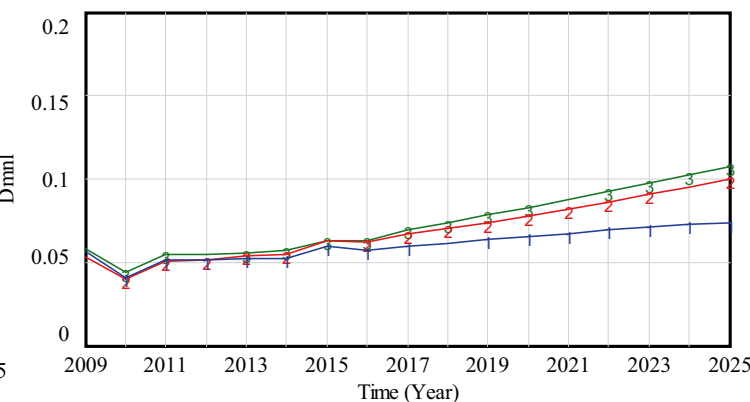

Huangshi RUTES : Q1 1

Huangshi RUTES : Q3 $\quad 3 \quad 3$

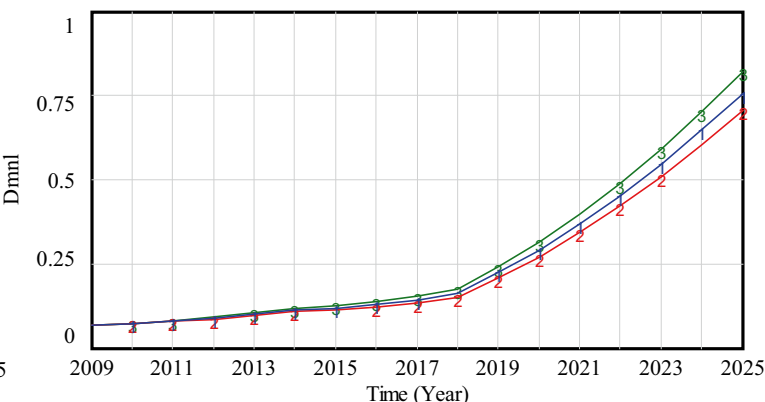

Yichang RUTES : Q1

Yichang RUTES : Q3

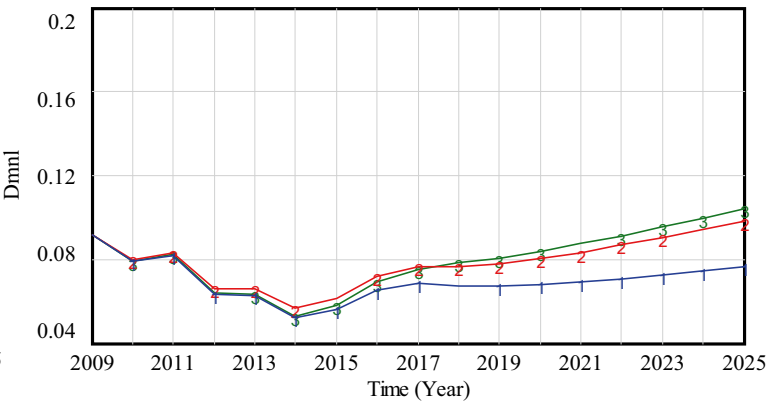

Ezhou RUTES : Q1 Ezhou RUTES : Q2 $\frac{1}{2}{ }_{2}$

Ezhou RUTES : Q3 $\rightarrow 3 \quad 3 \quad 3$

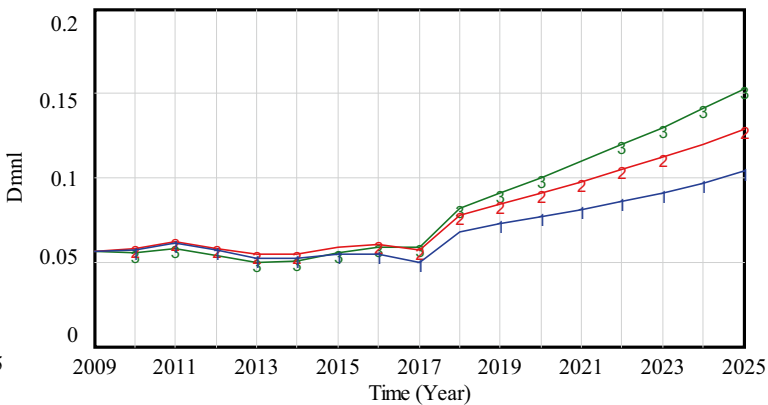

Xiaogan RUTES : Q1 Xiaogan RUTES : $\mathrm{Q} 2 \underset{2}{2} \mathrm{Z}_{2}$

Fig. 5 Ecological security levels of regional urban tourism in Hubei Province 


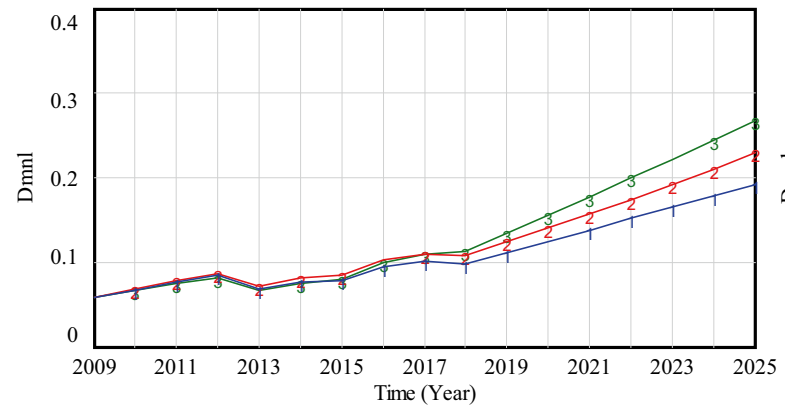

Jingzhou RUTES : Q1 — I I I J Jingzhou RUTES : Q3 - 3 3 Jingzhou RUTES : Q2 2

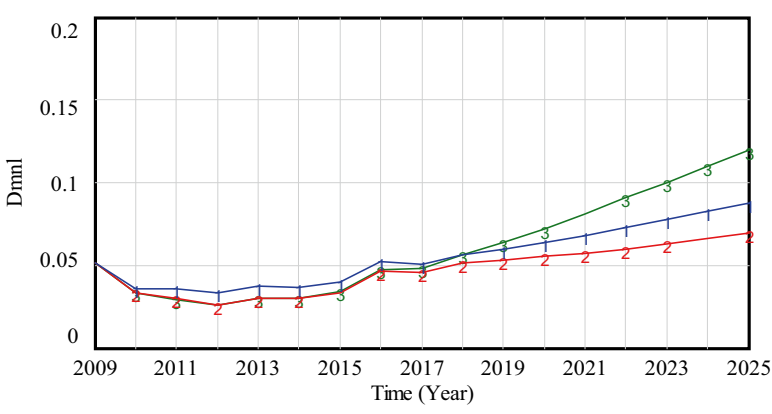

Xianning RUTES : Q1

Xianning RUTES : Q2 $\begin{array}{llll}2 & 2 & 2\end{array}$

Xianning RUTES : Q3

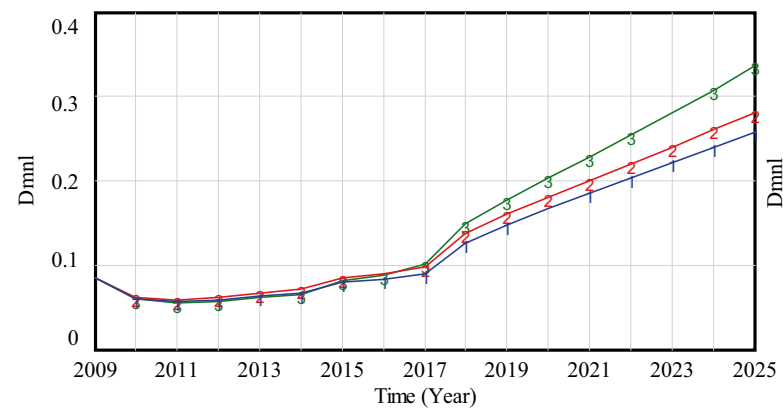

Enshi RUTES : Q1 1 1 1

Enshi RUTES : Q2 $\frac{2}{2} 2$

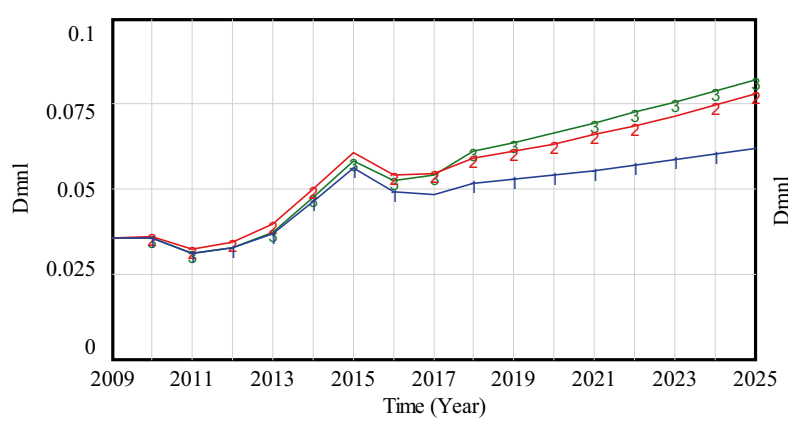

Qianjiang RUTES : Q1 1 1 Qianjiang RUTES : Q2 $2 \quad 2 \quad 2$

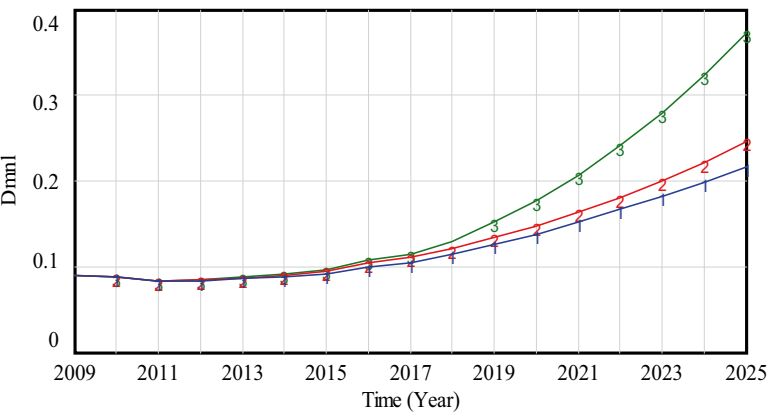

Huanggang RUTES : Q1 T Huanggang RUTES : Q2 $\frac{2}{2}$

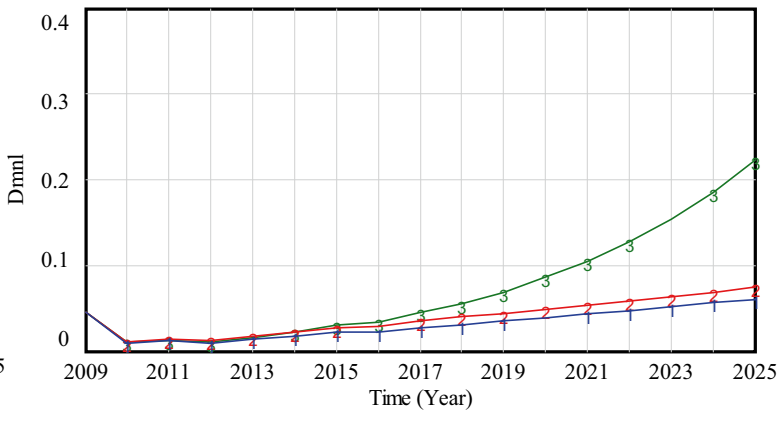

Suizhou RUTES : Q1 $\longrightarrow$ Suizhou RUTES : Q3 $\square$ Suizhou RUTES : Q2 $\begin{array}{llll}2 & 2 & 2\end{array}$

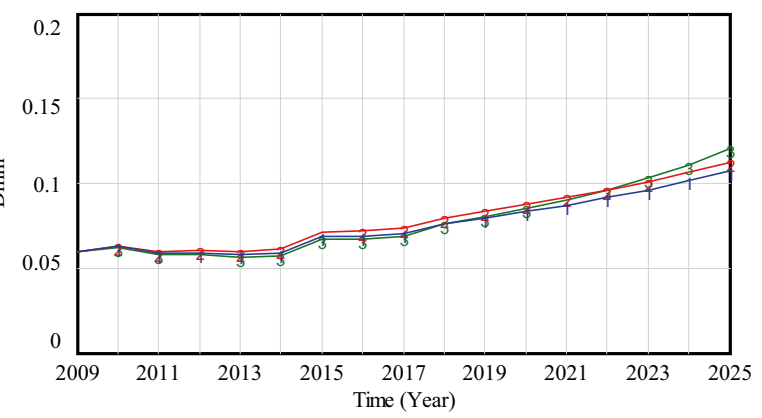

Xiantao RUTES : Q1 I I Xiantao RUTES : Q3 $\quad 3 \quad 3$ Xiantao RUTES : Q2 $\begin{array}{lll}2 & 2 & 2\end{array}$

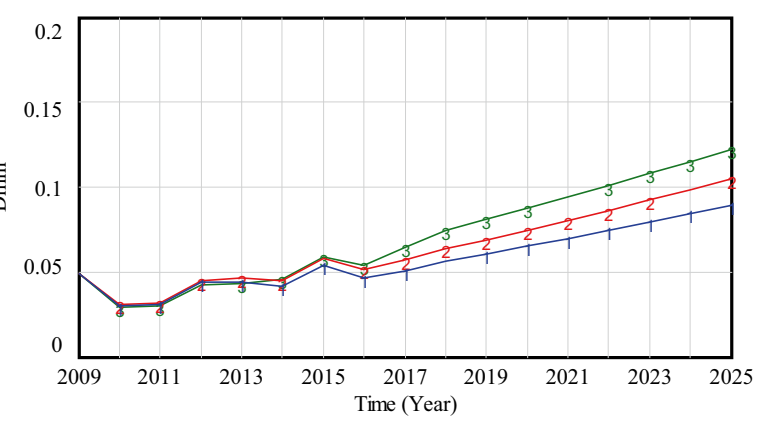

Tianmen RUTES : Q1 T I T T T T Tianmen RUTES : Q2 $2{ }_{2} \quad 2$

Fig. 5 (continued) 


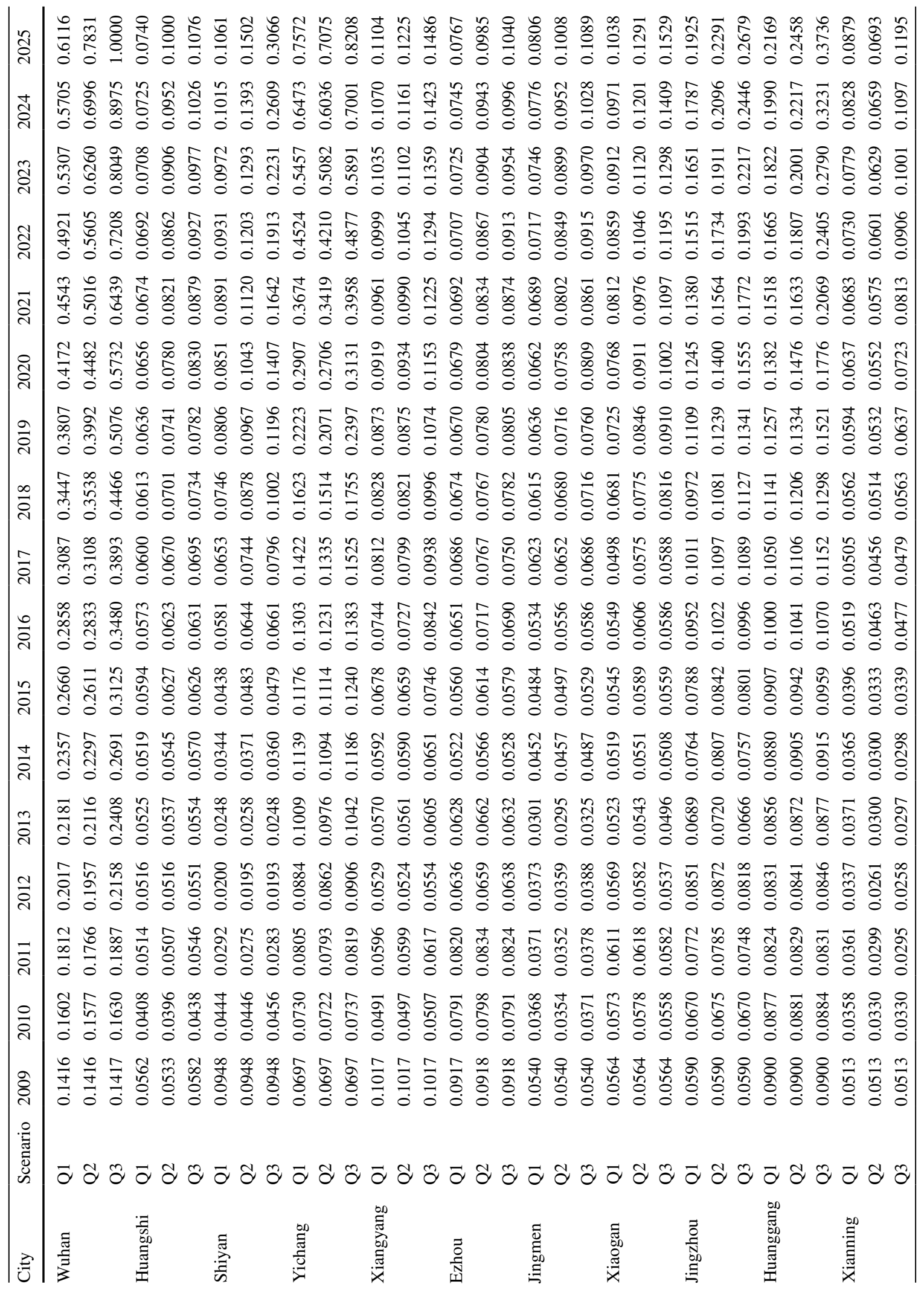




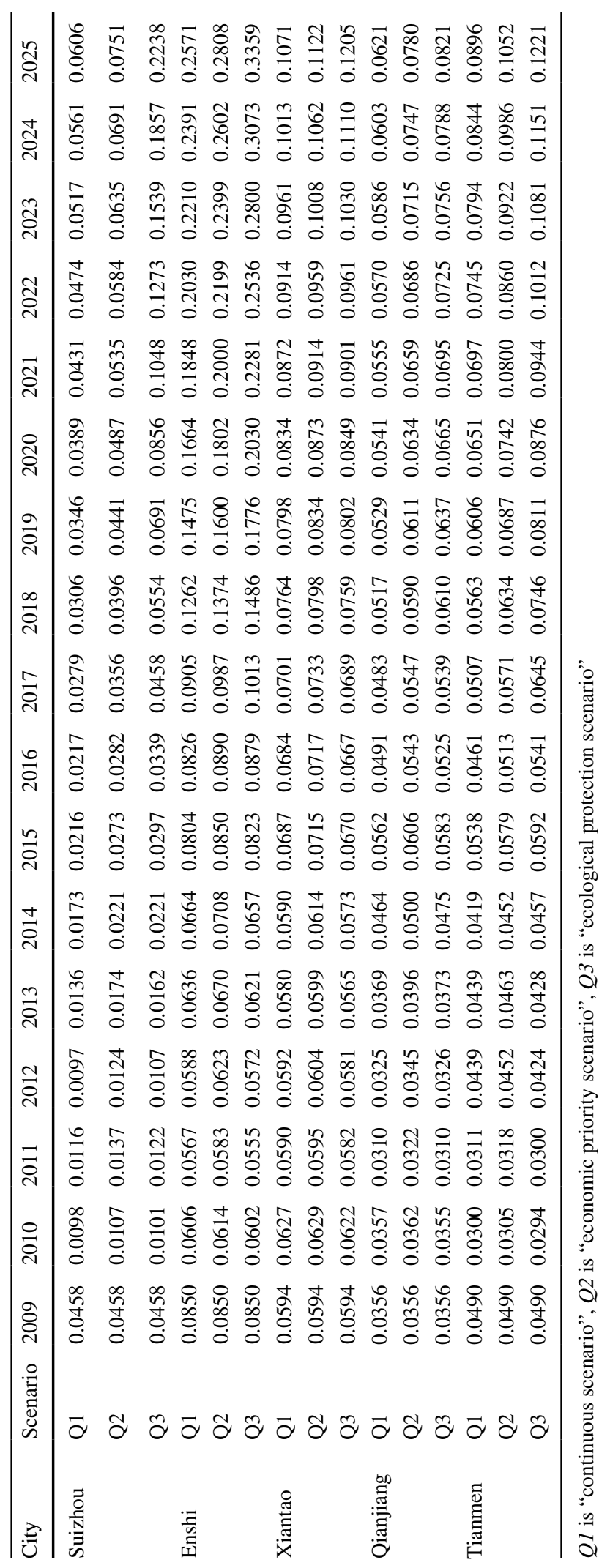


Fig. 6 Space-time evolution of the ecological security of regional urban tourism in Hubei Province
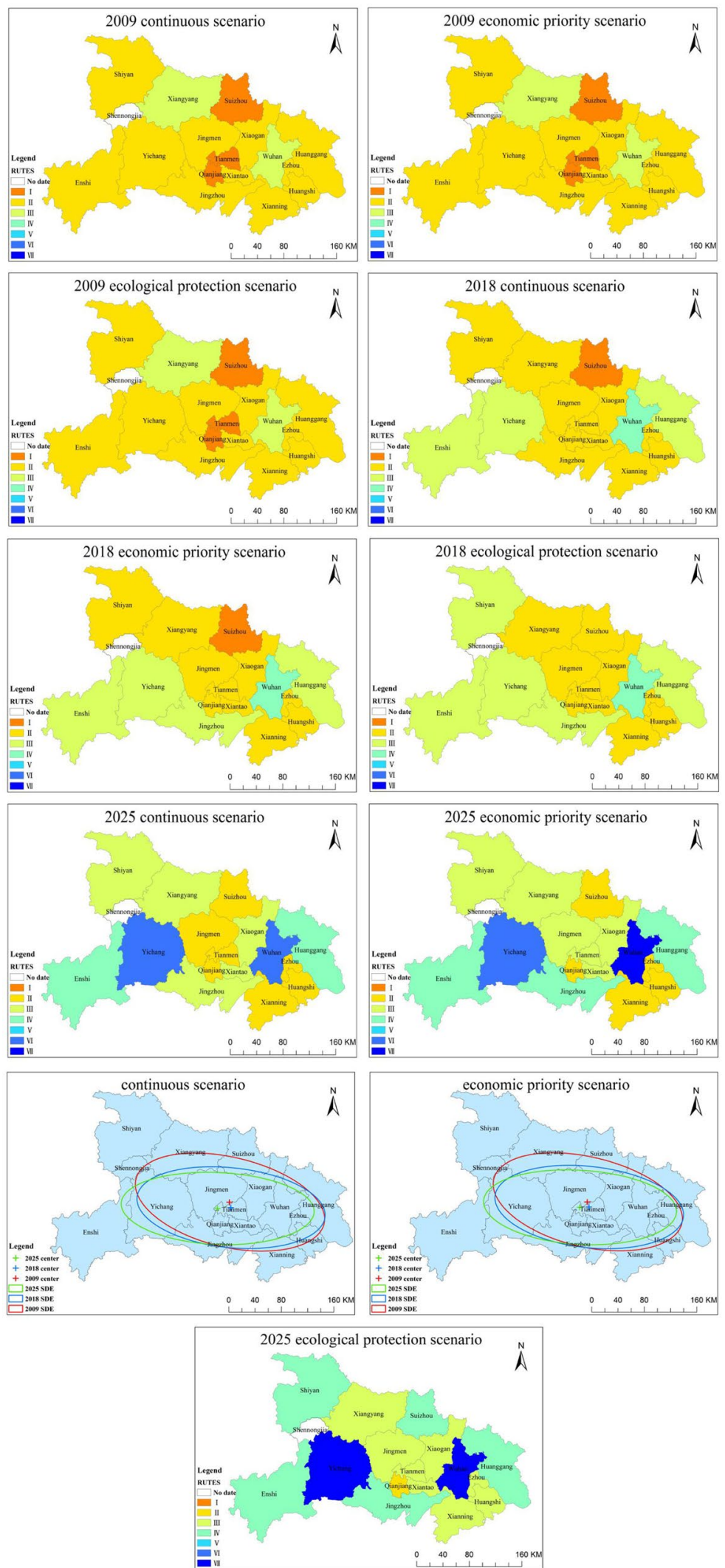
of regional urban tourism moves to the southwest, indicating that the overall ecological security level in the southwest is increasing; from 2009 to 2025, the ecological security level fluctuates and moves to the southwest as a whole, with the center of gravity being mainly in Tianmen. Under the continuous scenario, the overall security level is shrinking, with the standard deviation for the semi-minor ellipse axis falling from 0.9814 in 2009 to 0.7793 in 2025 , a reduction of 0.2021 . At the same time, the standard deviation for the semi-major axis expanded from 2.4848 in 2009 to 2.4983 in 2025, an increase of 0.0135 . Therefore, the ecological security level of regional urban tourism in Hubei Province is observed to fluctuate, deviating from true north and rotating in a clockwise direction from $101.7681^{\circ}$ in 2009 to $96.1651^{\circ}$ in 2018 to $93.3408^{\circ}$ in 2025 .

Under the economic priority scenario from 2009 to 2018 , the ecological security of regional urban tourism in Hubei Province level moves to the northeast, indicating that the overall ecological security in the northeast is increasing. From 2019 to 2025, the ecological security level of regional urban tourism moves to the southwest, indicating that the overall ecological security in the southwest is increasing, and from 2009 to 2025 , the ecological security level of regional urban tourism in Hubei Province fluctuates, moving to the southwest as a whole, and with the center of gravity mainly in Tianmen. Therefore, under the economic priority scenario, the ecological security level in Hubei Province is shrinking, with the standard deviation for the semiminor ellipse axis falling from 0.9821 in 2009 to 0.8042 in 2025 , a reduction of 0.1779 , and the standard deviation for the semi-major axis expanding from 2.4832 in 2009 to 2.4993 in 2025, an increase of 0.0161 . Therefore, under the economic priority scenario, the ecological security level of regional urban tourism in Hubei Province fluctuates, deviating from true north and
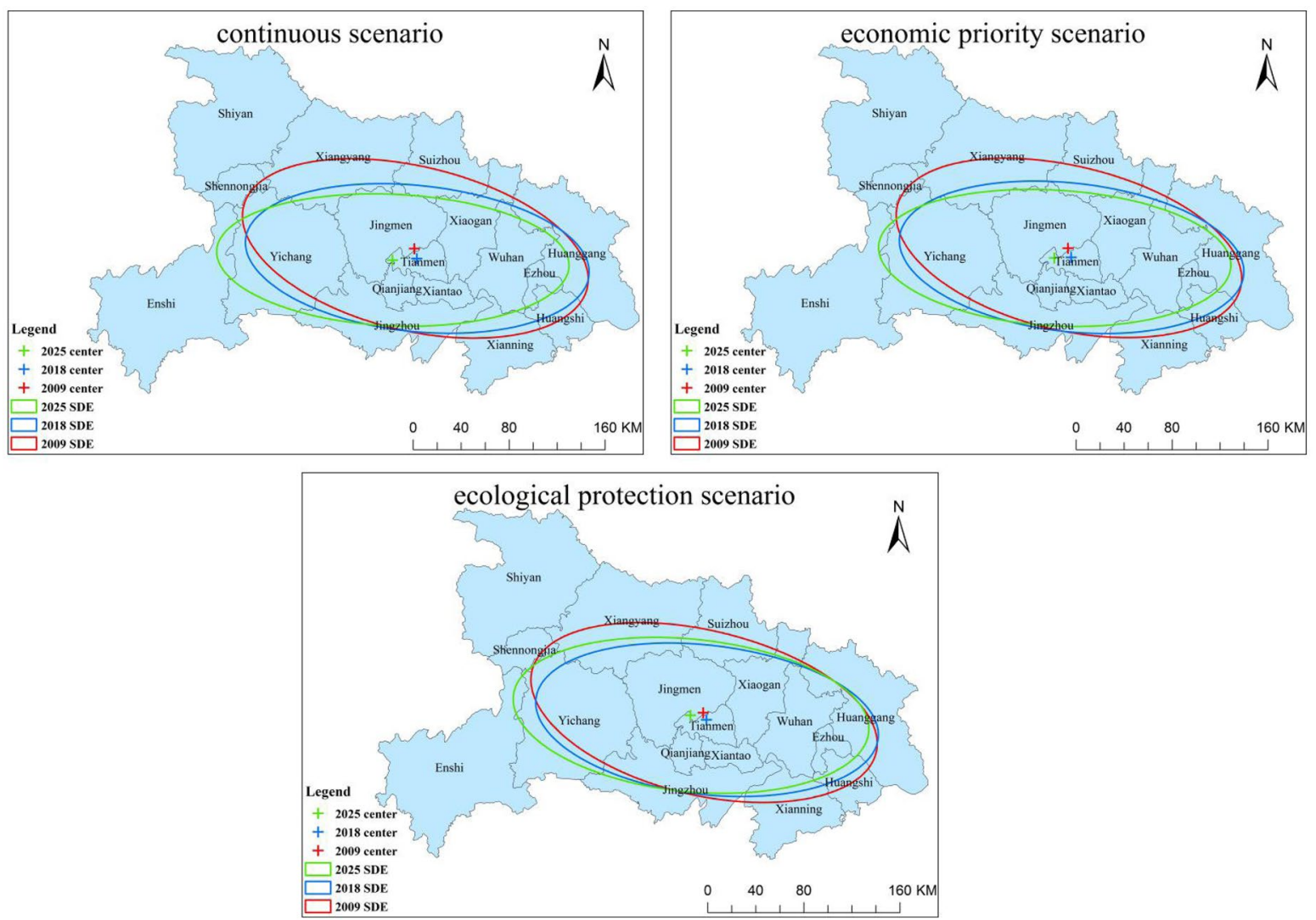

Fig. 7 Standard deviation ellipse for the ecological security levels of regional urban tourism in Hubei Province under the different scenarios 
Table 6 Elliptic parameters for the standard deviations in the ecological security levels of regional urban tourism in Hubei Province under the different scenarios

\begin{tabular}{lcccllc}
\hline Scenario & Year & Center X & Center Y & Semi-major axis & Semi-minor axis & Rotation angle \\
\hline Q1 & 2009 & 113.0005 & 30.8081 & 2.4848 & 0.9814 & 101.7681 \\
& 2018 & 113.0307 & 30.6901 & 2.4430 & 0.8666 & 96.1651 \\
& 2025 & 112.6863 & 30.6810 & 2.4983 & 0.7793 & 93.3408 \\
Q2 & 2009 & 112.9954 & 30.8103 & 2.4832 & 0.9821 & 101.7142 \\
& 2018 & 113.0351 & 30.6998 & 2.4488 & 0.8818 & 96.3898 \\
& 2025 & 112.7981 & 30.7000 & 2.4993 & 0.8042 & 94.0219 \\
Q3 & 2009 & 113.0037 & 30.8066 & 2.4858 & 0.9809 & 101.8036 \\
& 2018 & 113.0487 & 30.7222 & 2.4344 & 0.8838 & 96.6292 \\
& 2025 & 112.8236 & 30.7804 & 2.5264 & 0.9024 & 95.9448 \\
\hline
\end{tabular}

rotating in a clockwise direction from $101.7142^{\circ}$ in 2009 to $96.3898^{\circ}$ in 2018 to $94.0219^{\circ}$ in 2025 .

Under the ecological protection scenario from 2009 to 2018, the ecological security level of regional urban tourism in Hubei Province moves to the northeast, indicating that the overall ecological security in the northeast is increasing. From 2019 to 2025 , the ecological security level of regional urban tourism in Hubei Province moves to the southwest, indicating that the overall ecological security level in the southwest is increasing. Overall, from 2009 to 2025 , the ecological security of regional urban tourism in Hubei Province fluctuates, moving to the southwest as a whole, with the center of gravity mainly in Tianmen. Therefore, under the ecological protection scenario, the overall ecological security level of regional urban tourism in Hubei Province is shrinking, with the standard deviation of the semi-minor ellipse axis falling from 0.9809 in 2009 to 0.9024 in 2025, a reduction of 0.0785 , and the standard deviation of the semi-major axis expanding from 2.4858 in 2009 to 2.5264 in 2025 , an increase of 0.0406. Therefore, under the ecological protection scenario, the ecological security level of regional urban tourism in Hubei Province fluctuates, deviating from true north and rotating in a clockwise direction from $101.8036^{\circ}$ in 2009 to $96.6292^{\circ}$ in 2018 to $95.9448^{\circ}$ in 2025 .

\section{Conclusions}

In the human-land tourist destination relationship system, research on progressive tourism and ecological security is needed to alleviate the contradictions between the tourist ecological supply and demand systems in regional tourist destinations, to predict "hotspots" or "sensitive" areas in terms of the ecological security of regional urban tourism, and provide theoretical and practical support for the active promotion of early warning systems for ecological conflicts related to regional tourist destinations.

This study takes the regional urban space as the core perspective and, based on the influencing factors of the ecological security of regional urban tourism, assesses the economic, social, and environmental benefits of regional urban tourism development, discusses a theoretical system, and conducts empirical research to promote the resilient development of regional urban tourist destinations in China.

The main conclusions of this article are as follows:

1. Ecological security research systems based on time and space need to be built based on local conditions to determine the ecological security levels of regional urban tourism and ensure sustainable tourism development from environmental, social, and economic perspectives.

2. Taking Hubei Province as an example for empirical research, the ecological security levels of regional urban tourism in 16 Hubei Province cities are examined to assess the trends, from which it is found that under the "ecological protection scenario," the ecological security in the 16 cities has obvious differences, with Wuhan and Yichang having the higher levels. Overall, the ecological security levels of regional urban tourism in Hubei Province are fluctuating, with the overall movement being to the southwest and the center of gravity being mainly in Tianmen.

3. Relevant countermeasures are proposed to improve the ecological security level of regional urban tour- 
ism in Hubei Province, such as raising stakeholder awareness of ecological security issues related to tourism, strengthening regional tourism cooperation, and increasing tourism resource investments.

\section{Suggestions}

At the end of 2019 and early 2020, the coronavirus disease of 2019 broke out in Wuhan City, Hubei Province. Ecological security was threatened, and the tourism industry suffered heavy losses. At this time, stakeholders such as the government, tourism companies, tourists and residents of tourist destinations must collaborate to improve the ecological security level of regional urban tourism and restore the development of tourism in Hubei Province.

Based on the above research, this article puts forward the following suggestions. (1) As an "invisible hand," the government should increase its investment in social public resources and tourism environmental resources, ease tourism ecological pressure, improve the state of ecological tourism, and enhance ecological tourism responses to improve the level of ecological security in Hubei Province. (2) Tourism enterprises should establish a reward and punishment system to reward those who have made contributions to the protection of the tourism ecological environment and punish those who damage the ecological environment to ensure the quality of tourism practitioners. (3) Residents of tourist destinations should receive education on environmental protection on a regular basis to establish residents' self-control and selfeducation mechanisms so that residents can continue to receive tourism environmental protection education in their daily lives and improve their ecological security awareness in relation to tourism. (4) Tourists should enhance their awareness of green and low-carbon tourism, establish reasonable consumption concepts, rationally use tourism resources, and protect the ecological environment. To restore the development of tourism in Hubei Province as soon as possible, it is necessary to improve the level of the ecological security of regional urban tourism in Hubei Province and create a safe and harmonious atmosphere to attract more domestic and foreign tourists.

Author contribution Xiuping Yang contributed to the conception of the study and analysis, manuscript preparation, and performed the experiment. Yunting Jia and Chunmei $\mathrm{Li}$ performed the data analyses. Qinghe Wang and Shixin Zhang helped perform the analysis with constructive discussions.

Funding This work was supported by the National Natural Science Foundation of China (Grant No. 41961020), the National Natural Science Youth Fund Project of China (Grant No. 41501597), the Ministry of Education "Chunhui Plan" Cooperative Scientific Research Project (GS2019002), Gansu Humanities and Social Sciences Project (20ZZ20), Gansu Natural Science Fund Project (20JR10RA183), Lanzhou University of Technology Ph.D. Fund Project Funding, Lanzhou University of Technology Hongliu First-Class Discipline Support Direction "Management Decision Theory, Method and Application Construction Project," and Lanzhou University of Technology Research Development Guidance Fund Support Scheme.

Availability of data and materials The datasets generated during and/or analyzed during the current study are available from the corresponding author on reasonable request.

\section{Declarations}

Competing interests The authors declare no competing interests.

\section{References}

Banerjee, O., Boyle, K., Rogers, C. T., et al. (2018). Estimating benefits of investing in resilience of coastal infrastructure in small island developing states: An application to Barbados. Marine Policy, 90(3), 78-87.

Bangwayo-Skeete, P. F., \& Skeete, R. W. (2020). Modelling tourism resilience in small island states: A tale of two countries. Tourism Geographies, 1, 1-22.

Brahmasrene, T., \& Lee, J. W. (2017). Assessing the dynamic impact of tourism, industrialization, urbanization, and globalization on growth and environment in Southeast Asia. The International Journal of Sustainable Development and World Ecology, 24(4), 362-371.

Dey, J., Sakhre, S., Gupta, V., et al. (2018). Geospatial assessment of tourism impact on land environment of Dehradun, Uttarakhand India. Environmental Monitoring and Assessment, 190(4), 181-190.

Dogru, T., Marchio, E. A., Bulut, U., et al. (2019). Climate change: Vulnerability and resilience of tourism and the entire economy. Tourism Management, 72(6), 292-305.

Doronkina, I. G., Borisova, O. N., Malyutin, G. V., et al. (2014). Security in ecological tourism. World Applied Sciences Journal, 30(20), 39-40.

Espin, P. A., Mena, C. F., Pizzitutti, F. (2019). A model-based approach to study the tourism sustainability in an island environment: the case of Galapagos islands. In Urban Galapagos. Springer, Cham.

Hall, C. M., Timothy, D. J., \& Duval, D. T. (2003). Security and tourism: Towards a new understanding? Journal of Travel \& Tourism Marketing, 15(2-3), 1-18. 
Hedlund, T. (2011). The impact of values, environmental concern, and willingness to accept economic sacrifices to protect the environment on tourists' intentions to buy ecologically sustainable tourism alternatives. Tourism and Hospitality Research, 11(4), 278-288.

Jose, U. V., Nahar, M., Vijayakumar, S., et al. (2009). Balancing tourism and environment: The ETM model. International Scholarly and Scientific Research \& Innovation, 3(6), 1147-1152.

Li, X. G., Wu, L., Wu, Q., et al. (2015). The space-temporal pattern evolution of China's national ecological demonstration areas. Economic Geography, 35(8), 149-156.

Morteza, Z., Reza, F. M., Seddiq, M. M., et al. (2016). Selection of the optimal tourism site using the ANP and fuzzy TOPSIS in the framework of integrated coastal zone management: A case of Qeshm Island. Ocean \& Coastal Management, 130(6), 179-187.

Neven, Š, \& Tihomir, L. (2010). Marketing and environment management for tourism: Croatian experiences. Academica Turistica, Tourism \& Innovation Journal, 3(1), 73-80.

Pang, W., Ma, Y. F., \& Tang, Z. X. (2011). The coupling relationship and coordinated development between tourism economy and ecological environment: A case study of Xi' an City. Journal of Northwest University (environmental Science Edition), 41(6), 1097-1106.

Qin, X. N., \& Cheng, Y. (2019). Evaluation and type classification on Chinese tourist urban ecological security system: Based on the network DEA model with node weight. Scientia Geographica Sinica, 39(1), 156-163.

Shadova, Z., Tappaskhanova, E., Abrhám, J., et al. (2015). Tourism security and sustainability: A case study of North Caucasus region. Journal of Security \& Sustainability Issues, 4(3), 509-519.

Tan, S. H., Habibullah, M. S., Tan, S. K., et al. (2017). The impact of the dimensions of environmental performance on firm performance in travel and tourism industry. Journal of Environmental Management, 33(4), 66-74.

Wang, P., Kuang, F. M., Deng, Y. W., et al. (2014). On ecological safety evaluation for tourist destination based on touristic ecological footprint model: A case study of Nanyue Hengshan Mountain. Journal of Hengyang Normal University, 35(3), 54-60.

Weng, G. M., Pan, Y., \& Li, L. L. (2018). The eco-security grading and spatial-temporal evolution of tourism based on improved DPSI-DS model: a case study of the five northwestern Provinces along the Silk Road. Tourism Science, 32(6), 17-32.

Wu, C. Y., Guo, L. L., \& Yu, J. T. (2013). Dynamic simulation of regional ecological security of tourism. Systems Engineering, 31(2), 94-99.

Xu, S. G., Zuo, Y. F., \& Zhang, M. (2021). Evaluation of tourism ecological security and diagnosis of obstacle factors in China based on fuzzy object element model. Scientia Geographica Sinica, 41(1), 33-43.

$\mathrm{Xu}$, M., \& Liu, C. L. (2018). Tourism ecological security evaluation and obstacle factors analysis of Zhangjiajie. Resources and Environment in the Yangtze Basin, 27(3), 605-614.

Yang, X. P., \& Weng, G. M. (2019). A review of studies on tourism environment carrying capacity. Tourism Tribune, 34(4), 96-105.

Yang, X. P., \& Zhang, D. C. (2018). Study of coupling coordination between tourism economy and the new urbanization: Taking Lanzhou City as an example. Ecological Economy, 34(8), 112-116.

Zheng, Q. X., Kuang, Y. Q., Huang, N. S., et al. (2017). Spatiotemporal measurement and diagnosis of obstacle factors on tourism eco-security in Guangdong Province. Research of Soil and Water Conservation, 24(5), 252-258.

Zhou, B., Zhong, L. S., Chen, T., et al. (2015). Spatio-temporal pattern and obstacle factors of ecological security of tourism destination: A case of Zhejiang Province. Scientia Geographica Sinica, 35(5), 599-607.

Publisher's Note Springer Nature remains neutral with regard to jurisdictional claims in published maps and institutional affiliations. 